\title{
Prevalence and Characterization of Antibiotic Resistance Associated with Escherichia coli Isolated from Cultured Penaeus vannamei from Maharashtra, India
}

\author{
S.J. Abisha Juliet Mary*, M. Dhayanath and Tapas Paul \\ Department of Aquatic Animal Health Management, Central Institute of Fisheries Education, \\ Mumbai, 400061, India \\ *Corresponding author
}

A B S T R A C T

This study examined the prevalence of antimicrobial resistance associated

Keywords

E. coli, Shrimp,

Penaeus vannamei,

Antibiotic

susceptibility, erm gene

Article Info

Accepted:

15 June 2019

Available Online:

10 July 2019 with $E$. coli which is an indicator organism of contamination in shrimp ponds of Vannamei culture. A total of 173 isolates were isolated from 60 shrimp samples of selected areas of Maharashtra and were evaluated for isolation, identification and antibiotic sensitivity pattern for E. coli. Out of 173 isolates 67 isolates were found to be $E$. coli positive which is of 39.2 $\%$. The antimicrobial resistance profile of the tested Escherichia coli isolates to 12 different antibiotics revealed that all 67 isolates were sensitive to Furazolidone, Nalidixic acid, Neomycin, Nitrofurantoin, Norfloxacin, Trimethoprim whereas, the isolates showed resistant to ampicillin (75\%) and Erythromycin (61\%). The molecular characterization of erm genes which is predominantly associated with resistance among Enterococcus spp showed that $61.2 \%$ of the isolated E. coli were positive for ermB gene, whereas $42.5 \%$ of the isolates showed positive for ermC gene.

\section{Introduction}

Indian shrimp aquaculture showed a tremendous growth during the past decade, mainly due to the intensification in the shrimp farming practices. According to USDA, in 2015, India's export of shrimp was 382,959 tons which is about 9.8percent growth from the previous year (USDA, 2017). Moreover, India's cultured shrimp production in 2014-15 was about 426,500 MT, with a 30 percent growth from the previous year. This intensification leads to the emergence of several bacterial diseases with increasing use of antimicrobials for their control. Research indicates that the $70-80 \%$ of the drugs used in aquaculture ends up in the environment as large amount of those antimicrobial were used as therapeutic and prophylactic. Consequently, they may contribute to the major problem of 
development of drug resistance among shrimp pathogens. Antimicrobial resistant bacteria also known as 'superbugs' are a global concern as defined by WHO, the most urgent resistant trend. AMR risks the gains of Millennium Development Goals and endangers the Sustainable Development Goals. India has set highest record in shrimp entry line rejections in 2016. This rising rejection indicates the widespread use of antimicrobials in aquaculture for therapeutic and non-therapeutic uses in India (press release by the MPEDA). Accounting the usage of the antibiotics in pond management, about $27 \%$ used them to prevent or treat viral diseases. According to MPEDA report, in 2012-2015, about 17 cases of exported shrimp products were reported for the presence of prohibited substances such as nitrofuran metabolite (furazolidone), nitrofurazone and chloramphenicol. In recent studies in various countries, the prevalence of antimicrobialresistant bacteria in shrimp farms and shrimp products has been reported.

To analyse the antimicrobial resistance status of the enteric microflora of both fish and shrimp farms, E. coli also has been introduced as an indicator species in surveillance programs nowadays. This enteric bacteria in fish can also pose public health hazard (Rao and Gupta, 1978) as many studies have insisted that coliforms are not normal flora of fish and shellfish and they are not pathogenic to humans, but their presence indicates a higher risk of pathogens being present, which will affect humans more than they do aquatic organisms (Rudolfs et al., 1950; Cuelin, 1962; Rao et al., 1968; Cohen and Shuval, 1973; Evision and James, 1973; Lekshmy et al., 2014). The drug-resistant E. coli strains on farms might come from a variety of sources, including workers' hands, animal waste, shrimp feed, and water. However, little is known about the drug resistance and the genetic mechanisms of resistance in E. coli isolates from shrimps in India as most of the studies have focused on the human pathogens. An attempt is made in the present study to analyse the incidence of $E$. coli in the shrimp farms and its antibiotic resistance has been tested with 12 antibiotics.

\section{Materials and Methods}

The present study was conducted at the Department of Aquatic Animal Health, Central Institute of Fisheries Education, Mumbai, India. A total of 60 live shrimp samples were collected for the present study from selected fish farms of Thane, Naigoan and Bhayandar region of Maharashtra. Shrimps were anaesthetized by dipping in ice slurry and dissected in sterile condition. Stomach and intestine were removed and pooled separately by homogenising in $9 \mathrm{ml}$ of $2 \%$ saline solution using pestle and mortar. Each organ was then run through a series of dilution of $2 \%$ saline beginning at $1: 10$ to 1:10000 (1g tissue/ 9ml 2\% saline solution). The samples were subjected to bacterial culture examination using standard microbiology procedures. Each of the shrimp samples were transferred to $10 \mathrm{ml}$ of nutrient broth and incubated at $37^{\circ} \mathrm{C}$ for $22-24$ hours to resuscitate the organisms. A loopful of sample was then streaked on nutrient agar plates in progressive fashion in order to obtain isolated colonies of bacteria. These petri plates were incubated for $24 \mathrm{hrs}$ at $37^{\circ} \mathrm{C}$. After $24 \mathrm{hrs}$ of incubation these isolated colonies were cultured on eosin methylene blue agar (EMB) plates for isolation of Escherichia coli. Reinoculation of the selected colonies were continued until pure bacterial colonies were obtained. Pure isolated bacteria were preserved for further analysis using agar slants. The growth was examined for the colonial morphology and pigmentation, and different types of colonies were sub-cultured on separate nutrient agar plates in order to obtain a pure culture. 
The confirmation of the isolates as Escherichia coli were done using Gram's staining, Catalase test, Oxidase test, Coagulase test and 12 biochemical tests for Escherichia coli. Antibiotic sensitivity test (AST) was conducted as per the disc diffusion method prescribed by Kirby et al., (1966). Spread the overnight culture on Mueller-Hinton agar plate surface evenly using sterile cotton swabs. Place the filter paper discs containing standardized quantities of antimicrobial drug onto the agar surface within 15 minutes of spreading the culture. These petri plates were incubated at $37^{\circ} \mathrm{C}$ for $18-24 \mathrm{hrs}$. To conduct antibiotic sensitivity test, 12 antibiotic discs were selected viz., Ampicillin (10 mcg), Aztreonam (30mcg), Cephalothin (30 mcg), Chloramphenicol (30mcg), Erythromycin (15mcg), Furazolidone (30mg), Nalidixic acid (30mcg), Neomycin (30mcg), Nitrofurantoin (300mcg), Norfloxacin (10mcg), Trimethoprim (300mcg) and Tetracycline (30mcg).

Bacterial cultures on nutrient agar slants were used to extract crude DNA, by the use of boiling cell lysis extraction method. A single colony of bacterial cells was suspended in 50 $\mu l$ of distilled water and vortexed shortly. The suspension was heated at $99^{\circ} \mathrm{C}$ for $5 \mathrm{~min}$ and then was chilled in ice for $10 \mathrm{~min}$. The cell debris was pelleted by centrifugation at 13,400 $\mathrm{g}$ for $2 \mathrm{~min}$ and $5 \mu \mathrm{l}$ of clear supernatant was used as the DNA template in a PCR. The PCR was done using previously described primers specific for erm B and ermC genes (Nguyen $e t$ al., 2009). Table 1 shows the details of the primers used in this study. The PCR products were then separated using electrophoresis on $1.5 \%$ agarose gel, and visualised under UV by staining with ethidium bromide.

\section{Results and Discussion}

Out of 60shrimp samples, 173 bacterial isolates were isolated and characterized with standardized laboratory methods. Of the 173 isolates 67 (39\%) were found positive for Escherichia coli. Faridullah et al., reported $60 \%$ prevalence of positive isolates of $\mathrm{E}$. coli from shrimp samples of 30 numbers in Bangladesh (Faridullah et al., 2016). Roy et $a l$., isolated $12 \mathrm{E}$. coli samples in 48 samples of shrimp intestine farmed shrimp (Roy et al., 2013). Moreover, Sugumar et al., (2001) have reported increased coliform loads in shrimp farming system. This study reveals that all the isolates that were gram negative, oxidase negative, catalase positive. All Escherichia coli strains gave metallic sheen on EMB agar. Biochemical test proposed by Oliver et al., (1992), and Alsina et al., (1994) were done for confirmation of Escherichia coli.

The isolates showing positive reaction for the Nitrate reduction test, Methyl red test, Indole test, ONPG test, Lysine utilization test, Lactose, Glucose, Sucrose and Sorbitol sugar tests while negative with Voges Proskauer's test and Citrate utilization test were confirmed as Escherichia coli (Koneman et al., 2001) which is described in the Table 2.

The isolated 173 bacterial colonies were subjected to antimicrobial susceptibility testing proposed by Kirby \& Bauer (1966). The reported commonly used antibiotics in shrimp and fish aquaculture by Costa et al., 2015, Holmstrom et al., 2003, Almada et al., 2012 were used for this study. Vieria et al., in his study confirmed that more than $90.5 \%$ of strains of Escherichia coli showed a variety of resistance profiles to the tested antibiotics (Vieria et al., 2010). In the present study, out of the 67 tested isolates, most of the isolates were resistant to ampicillin and erythromycin antibiotics. The antimicrobial resistance profile of the tested isolates Escherichia coli to different antibiotics revealed that out of the 67 isolates, 50 isolates $(75 \%)$ were resistant to Ampicillin, 35 isolates (53\%) were resistant to Cephalothin, 23isolate (35\%) were resistant to 
Aztreonam and 41 isolates (61\%) were resistant to Erythromycin. In study conducted by Changkaew the resistant isolates were found in shrimp is of $29.6 \%$ which is 8 of 27 isolates, and high resistance rates were found for tetracycline, ampicillin, and trimethoprim (Changkaew, et al., 2005). The Table 3 gives the brief details on the antimicrobial resistant profile of those isolated E.coli. Intermediate resistance were observed against five antibiotics - Ampicillin, Aztreonam,
Cephalothin and Erythromycin. Almost 60 $(90.2 \%)$ isolates of E. coli showed intermediate resistance to one or more antibiotics. No isolate showed complete sensitivity against all the antibiotics tested. But all the isolates showed complete sensitivity towards Chloramphenicol, Trimethoprim, Nalidixic acid, Norfloxacin, Tetracycline, Nitrofurantoin and Furazolidone (Fig. 1-4).

Table.1 Showing primers used for molecular characterization of $E$. coli

\begin{tabular}{|l|l|l|l|l|l|}
\hline $\begin{array}{l}\text { Target } \\
\text { gene }\end{array}$ & Primer & Sequence & $\begin{array}{l}\text { Produc } \\
\text { t size }\end{array}$ & $\begin{array}{l}\text { Annealing } \\
\text { temperature }\end{array}$ & Reference \\
\hline ermB & ermBF & GAAAAAGTACTCAACCAAATA & 639 & 45 & $\begin{array}{l}\text { Nguyen } \text { et } \\
\text { al., } 2009\end{array}$ \\
\cline { 2 - 5 } ermBR & AATTTAAGTACCGTTACT & & & $\begin{array}{l}\text { Nguyen } \text { et } \\
\text { al., } 2009\end{array}$ \\
\hline
\end{tabular}

Table.2 Results of biochemical tests for Escherichia coli obtained

\begin{tabular}{|l|l|l|l|l|l|}
\hline S. No & Tests & Positive & Negative & \\
\cline { 5 - 6 } & & No & $\%$ & No & $\%$ \\
\hline 1. & Methyl red & $61 / 67$ & $91.67 \%$ & $06 / 67$ & $08.33 \%$ \\
\hline 2. & Voges Proskauer's & $6 / 67$ & $08.33 \%$ & $61 / 67$ & $91.67 \%$ \\
\hline 3. & Citrate utilization & $14 / 67$ & $20.83 \%$ & $53 / 67$ & $79.17 \%$ \\
\hline 4. & Indole & $67 / 67$ & $100.00 \%$ & - & - \\
\hline $\mathbf{5}$ & Nitrate reduction & $67 / 67$ & $100.00 \%$ & - & - \\
\hline 6. & ONPG & $64 / 67$ & $95.83 \%$ & $3 / 67$ & $04.17 \%$ \\
\hline 7. & Lysine utilization & $59 / 67$ & $87.50 \%$ & $8 / 67$ & $12.50 \%$ \\
\hline 8. & Lactose & $64 / 67$ & $95.83 \%$ & $3 / 67$ & $04.17 \%$ \\
\hline 9. & Glucose & $67 / 67$ & $100.00 \%$ & - & - \\
\hline 10 & Sucrose & $64 / 67$ & $95.83 \%$ & $3 / 67$ & $04.17 \%$ \\
\hline 11. & Sorbitol & $50 / 67$ & $75.00 \%$ & $17 / 67$ & $25.00 \%$ \\
\hline
\end{tabular}


Table.3 Antimicrobial resistant profile of isolate E. coli

\begin{tabular}{|c|c|c|c|}
\hline Antibiotics & Resistant & Intermediate & Sensitive \\
\hline Ampicillin & $50(67)$ & $10(67)$ & $7(67)$ \\
\hline Cephalothin & $35(67)$ & $22(67)$ & $10(67)$ \\
\hline Aztreonam & $23(67)$ & $15(67)$ & $29(67)$ \\
\hline Erythromycin & $41(67)$ & $11(67)$ & $15(67)$ \\
\hline Furazolidone & - & - & $67(67)$ \\
\hline Nalidixic acid & - & - & $67(67)$ \\
\hline Nitrofurantoin & - & - & $67(67)$ \\
\hline Norfloxacin & - & - & $67(67)$ \\
\hline Trimethoprim & - & - & $67(67)$ \\
\hline Tetracycline & - & - & $67(67)$ \\
\hline Chloramphenicol & - & - & $67(67)$ \\
\hline Neomycin & - & - & $67(67)$ \\
\hline
\end{tabular}

\section{Antimicrobial Susceptibility profile of E.coli}
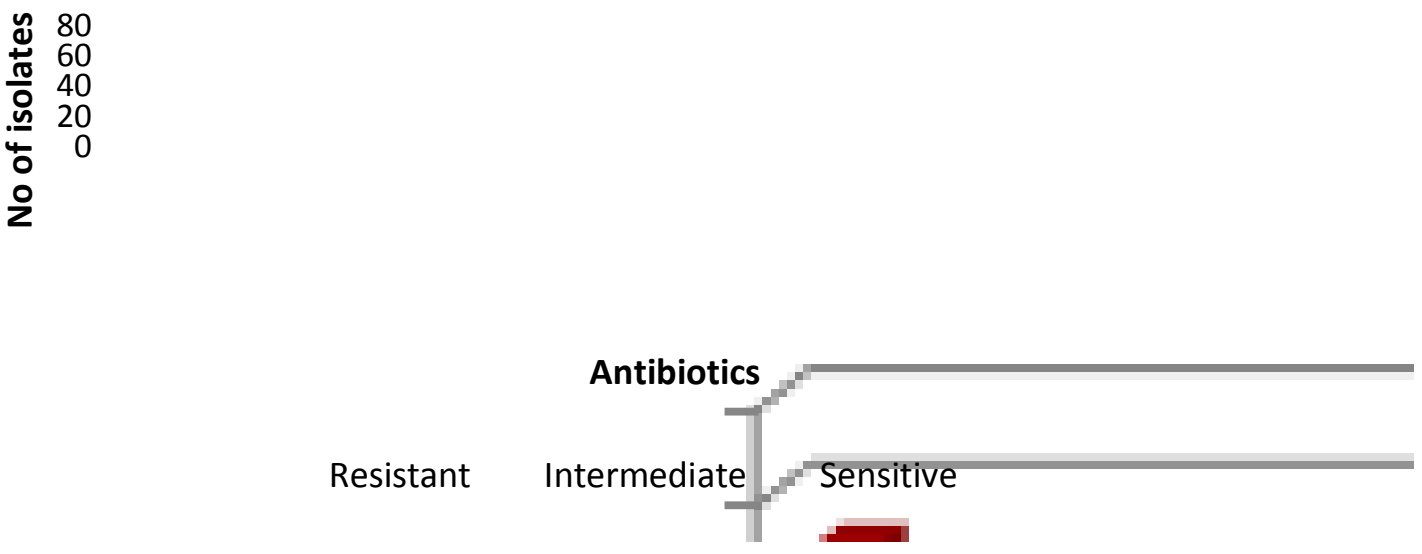

Fig.1 Escherichia coli on EMB agar with metallic sheen

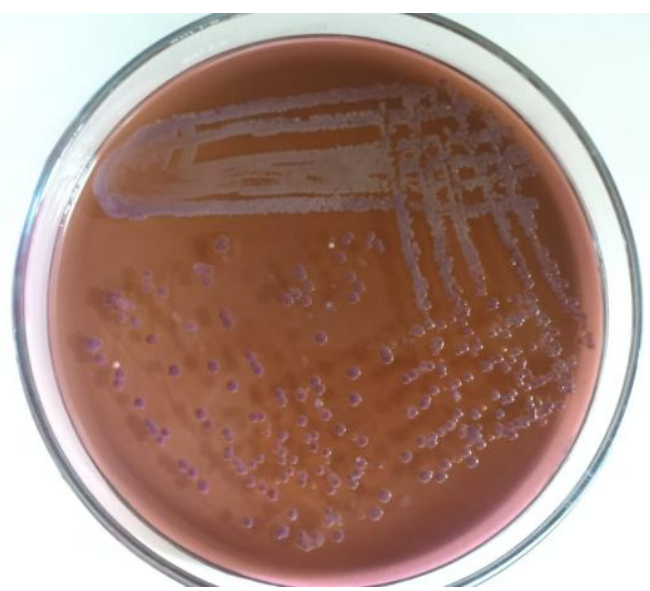


Fig.2 Antimicrobial susceptibility test conducted on E. coli isolates

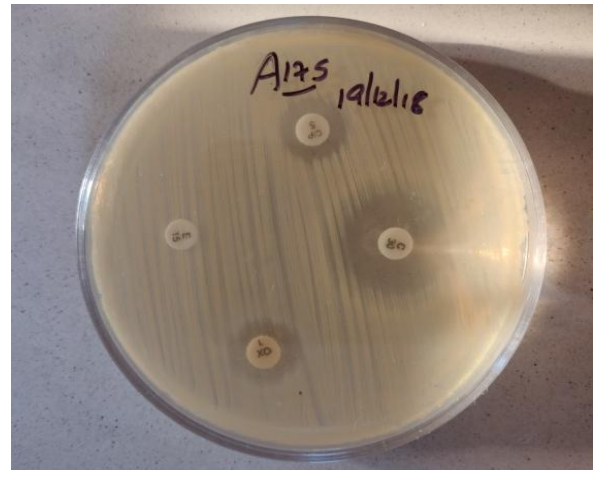

Fig.3 Samples showing positive of 639 bp ermB gene. Lane 1- ladder (100bp), Lane 1-5 isolated E.coli samples, Lane 6- Positive control

$$
\begin{array}{llllllll}
1 & 2 & 3 & 4 & 5 & 6 & 7 & 8
\end{array}
$$

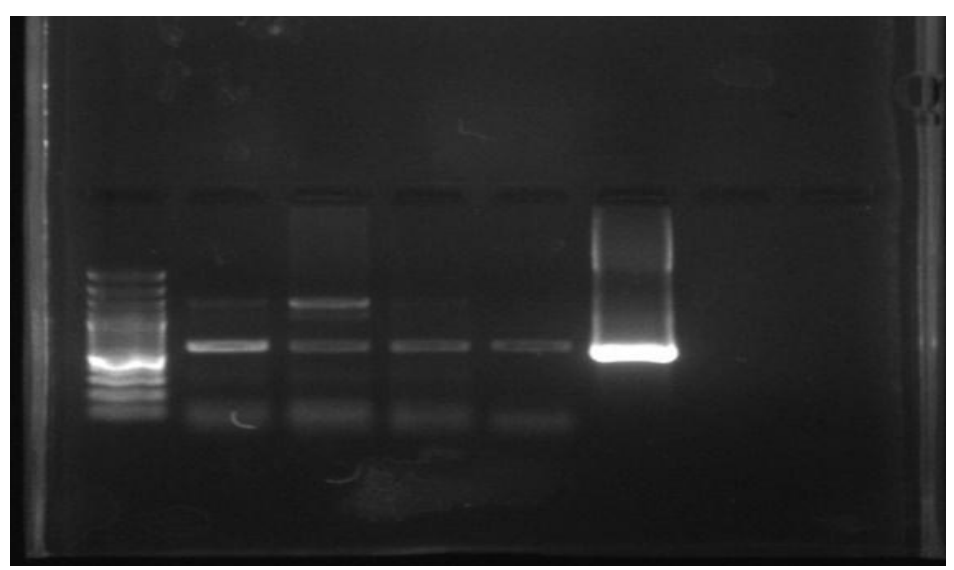

Fig.4 Samples showing positive of 642 bp ermC gene. Lane 1- ladder (100bp), Lane 1- Positive control, Lane 2-6 - isolated E.coli samples

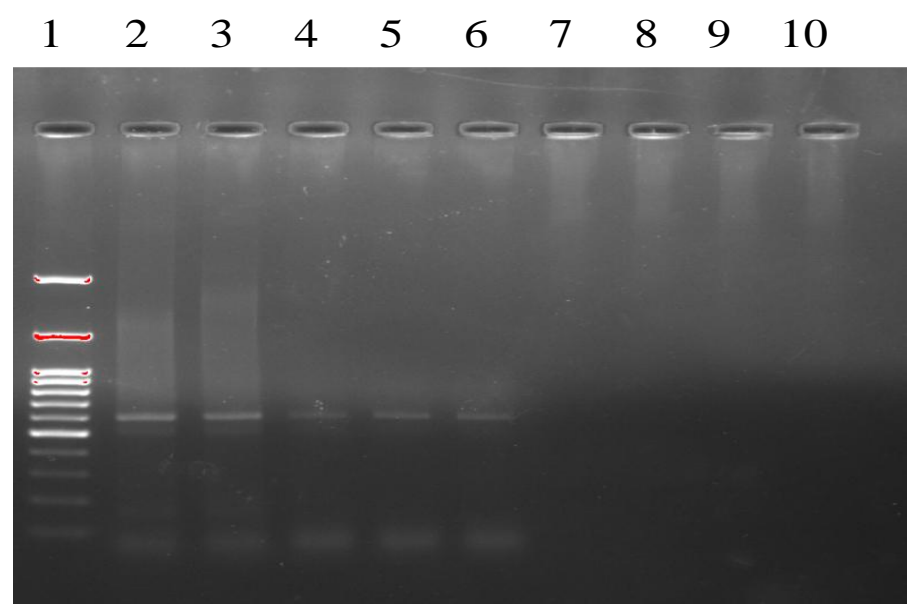


A total of 41 isolates showed resistance against erythromycin. These bacteria were tested for the prevalence of ermB and ermC gene using primers given by Nguyen et al., 2009 which yielded an amplicon of $639 \mathrm{bp}$ and 642bp respectively. Erm-directed resistance can either be constitutive or macrolide inducible (Weisblum et al., 1995) and it should be noted that the possession of erm genes was predominantly associated with resistance among Escherichia spp (Petersen et al., 2003; Hoa et al., 2008).

Of the total 41 tested, 25 bacteria were positive for $e r m B$ gene, which indicated a high level (61.2\%) of prevalence, whereas 17 isolates showed positive for ermC gene, which is about $42.5 \%$ prevalence.

Due to the bioaccumulation and toxic actions of antibiotics used in farming, this emergence of the resistance genes can have an impact in environment and also in public health.

So the molecular characterization of the antimicrobial resistant genes were focused in this study to know the clear cut data on the development of antimicrobial resistance in the shrimp farming environment.

\section{Acknowledgement}

We extend our sincere gratitude to Director, Central Institute of Fisheries Education, Mumbai for providing necessary facilities and funds to carry out this work.

\section{References}

Almada, M.C. and Espinosa-Plascencia, A., 2012. The use of antibiotics in shrimp farming. In Health and Environment in Aquaculture. In Tech.

Alsina, M. and Blanch, A.R. 1994. A set key for biochemical identification of environmental Vibrio species. J. Appl. Bacteriol., 76: 79-85
Bauer, A.W., Kirby, W.M.M., Sherris, J.C. and Turck, M., 1966. Antibiotic susceptibility testing by a standardized single disk method.American journal of clinical pathology, 45(4_ts), pp.493-496.

Changkaew, K., Utrarachkij, F., Siripanichgon, K., Nakajima, C., Suthienkul, O. and Suzuki, Y., 2014. Characterization of antibiotic resistance in Escherichia coli isolated from shrimps and their environment. Journal of food protection, 77(8), pp.1394-1401.

Cohen, J. and Shuval, H.I., 1973. Coliforms, fecal coliforms and fecal streptococci as indicator of water pollution. Water Air Soil Pollut, 2: 85-95

Costa A, R., Araújo, R.L., Souza, O.V. and Vieira, R.H.S.D.F., 2015. Antibioticresistant Vibrios in farmed shrimp. BioMed research international,

Cuelin, A., 1962. Polluted waters and the contamination of fish. Fish Food, 2: 4814500.

Evision, L.M. and James, A.; 1973. A comparison of the distribution of intestinal bacteria in British and African water sources. Appl. Bacteriol., 36: 109118.

Faridullah, M., Roy, V.C. and Lithi, U.J., 2016. Prevalence of Salmonella and Escherichia coli contamination in shrimp (Penaeus monodon) farms, depots and processing plants in different areas of Bangladesh. Asian Journal of Medical and Biological Research,2(2), pp.171176.

Hoa N.T., Chieu T.T., Nghia H.D., Mai N.T., Anh P.H., Wolbers M., Baker S., Campbell J.I., Chau N.V., Hien T.T., et $a l$. , 2008. The antimicrobial resistance patterns and associated determinants in Streptococcus suis isolated from humans in southern Vietnam. BMC Infect. Dis. 2011 doi: 10.1186/14712334-11-6.

Hoa, Phuong, Nonaka, P.T., Hung, L., Viet, P., Suzuki, S. 2008. Detection of the sull, sul2, and sul3 genes in sulfonamideresistant bacteria from wastewater and 
shrimp ponds of North Vietnam. Sci. Total Environ. 405, 377e384.

Holmoström K, Gräslund S, Wahlström A, Poungshompoo S, Bengtsson BE, Kautsky N., 2003. Antibiotic use in shrimp farming and implications for environmental impacts and human health. Int J Food Sci Technol 38: 255-266

Lekshmy, S., Soumya, W., Nansi Mole, A., Vimal Raj, R.V., BinushmaRaju, S.S., Gayathri Devi, T.V. and Radhakrishnan, T., 2014. Incidence of E. coli in extensive shrimp culture systems of Kerala. Indian Journal of Scientific Research,9(1), pp.117-126.

Mpeda, C., 2016. The Marine Products Export Development Authority.

Nguyen, M.C.P., Woerther, P.L., Bouvet, M., Andremont, A., Leclercq, R. and Canu, A., 2009. Escherichia coli as reservoir for macrolide resistance genes. Emerging infectious diseases, 15(10), p.1648.

Oliver, J.D., Guthrie, K., Preyer, J., Wright, A., Simpson, L.M., Siebling, R. and Morris, J.G., 1992. Use of colistin-polymyxin Bcellobiose agar for isolation of Vibrio vulnzjcus from the environment. Applied and Environmental Microbiology 58, 737- 739.

Petersen, A. and Dalsgaard, A., 2003. Species composition and antimicrobial resistance genes of Enterococcus spp., isolated from integrated and traditional fish farms in Thailand. Environmental

Microbiology, 5(5), pp.395-402.

Rao, C.C.P and Gupta, S.S. 1978. Enteropathogenic E. coli and other coliforms in marine fish. Fish. Tech., 15: $45-47$
Rao, D.U., Parhad, N.H., Rao, C.S. and Rao, K.S. 1968. Coliforms as indicator of faecal contamination. Environ. Hlth., 10: 21-24

Roy, D., Biswas, B., Islam, H.M.R. and Ahmed, M.S. (2013) Rapid identification of enterovirulent Escherichia coli strains using polymerase chain reaction from shrimp farms. Pak J BiolSci 16, 12601269.

Rudolfs, W., Falk, L. and Ragotskie, R.A. 1950. Literature review on the occurrence and survival of enteric, pathogenic and relative organisms in soil, water sewage and sludge on vegetation. Sewage Ind. Waste, 22: 1261.

Sugumar, G., Abraham, T.J. and Shanmugham, S. 2001. Human pathogenic bacteria in shrimp farming system. Indian J. Microbiol., 41: 269-274

USDA report on India's Shrimp Sector Growing Steadily. New Delhi. India. IN7030. 2/22/2017.

Vieira, Regine HS Dos F., Edirsana MR Carvalho, Fátima CT Carvalho, Camila M. Silva, Oscarina V. Sousa, and Dália P. Rodrigues. 2010. "Antimicrobial susceptibility of Escherichia coli isolated from shrimp (Litopenaeusvannamei) and pond environment in northeastern Brazil." Journal of Environmental Science and Health Part B 45, no. 3: 198203.

Weisblum, B., 1995. Erythromycin resistance by ribosome modification. Antimicrobial agents and chemotherapy, 39(3), p.577.

\section{How to cite this article:}

Abisha Juliet Mary, S.J., M. Dhayanath and Tapas Paul. 2019. Prevalence and Characterization of Antibiotic Resistance Associated with Escherichia coli Isolated from Cultured Penaeus vannamei from Maharashtra, India. Int.J.Curr.Microbiol.App.Sci. 8(07): 1790-1797. doi: https://doi.org/10.20546/ijcmas.2019.807.213 